\title{
PREDIKSI DISTRIBUSI SAND MENGGUNAKAN PEMODELAN GEOSTATISTIK
}

\author{
Elistia Liza Namigo \\ Jurusan Fisika. FMIPA. Universitas Andalas \\ elistializanamigo@fmipa.unand.ac.id
}

\begin{abstract}
ABSTRAK
Gambaran distribusi fasies dan heterogenitas geologi yang representatif sangat diperlukan dalam pengelolaan aktivitas eksplorasi dan eksploitasi migas di bawah permukaan. Telah dilakukan pemodelan distribusi sand pada formasi Missisauga, lapangan Penobscot dengan menggunakan tiga algoritma berbasis grid yaitu Sequential Indicator Simulation (SIS) dan Truncated Gaussian Simulation (TGS) dan Multipoint Geostatistic (MPG). SIS dan TGS yang merupakan algoritma yang berbasis variogram, mampu menghasilkan model yang merepresentasikan korelasi spasial antar sumur dengan cukup baik namun belum secara optimal menangkap geometri fasies akibat sifat dari variogram yang hanya bisa memodelkan kontinuitas spasial antara dua lokasi pada satu waktu. TGS lebih unggul dibandingkan SIS pada aspek keterhubungan lateral dari sand channel dan distribusi fasies terlihat lebih well-ordered (sand-shalysand-shale).. MPG yang merupakan metode yang didasarkan pada data singkapan menawarkan korelasi lateral yang lebih baik.
\end{abstract}

Kata kunci : variogram, pemodelan fasies, Sequential Indicator Simulation, Truncated Gaussian Simulation, Multi-point Statistics.

\section{PENDAHULUAN}

Geostatistik digunakan secara luas untuk membuat model kuantitatif reservoir dalam skala lapangan berdasarkan data geologi, data seismik dan data produksi. Tujuan dari geostatistik adalah memprediksi dan memetakan sebaran sebuah parameter secara spasial sehingga diperoleh gambaran tentang heterogenitas dan kontinuitas reservoir (Deustch, 2002). Peta distribusi heterogenitas dan kontinuitas reservoir sangat penting dalam penentuan flow response dan untuk membuat model aliran fluida untuk memprediksi efisiensi dari proses recovery yang berbeda-beda. Dua dari sekian banyak algoritma yang luas digunakan dalam pemodelan distribusi fasies adalah Sequential Indicator Simulation (SIS), Truncated Gaussian Simulation (TGS). SIS didasarkan pada kriging/co-kriging untuk memperoleh conditional cumulative distribution function (CCDF) dari fasies batuan. Dari CCDF, sebuah fasies batuan dibuat menggunakan simulasi Monte Carlo di setiap node (Falivene et al. (2007). TGS didasarkan pada single Gaussian Random Field (GRF) dalam menghasilkan fasies batuan. Metode ini tepat digunakan pada situasi dimana fasies batuan menunjukkan keteraturan distribusi spasial seperti pada lingkungan pengendapan dan formasi sedimen (Cáceres et al., 2010). Metode SIS dan TGS samasama didasarkan pada kriging/co-kriging (variogram) yang merupakan geostatistik duatitik maka reproduksi pola-pola kompleks 3D tidak bisa dilakukan. Untuk itu Strebelle (2005) mengajukan suatu pendekatan berdasarkan geostatistik banyak-titik (multi-point geostatistics). Multipoint Geostatistics (MPG) merupakan algoritma baru yang secara teoritis diharapkan dapat memodelkan fitur-fitur geologi yang lebih kompleks. MPG memerlukan sebuah 'training image' sebagai pengganti variogram. Training image adalah representasi numerik dari struktur geologi dan pola pola yang akan dibuat pada model. Poin penting pada MPG adalah bagaimana menghasilkan algoritma geostatistik yang bisa mereproduksi training image dan pada saat yang sama juga sesuai dengan data sumur dan data seismik. (Caers, J. \& Zhang, T, 2002; Strebelle, S.,2002). Skematik dari metode MPG dapat dilihat pada Gambar 1 


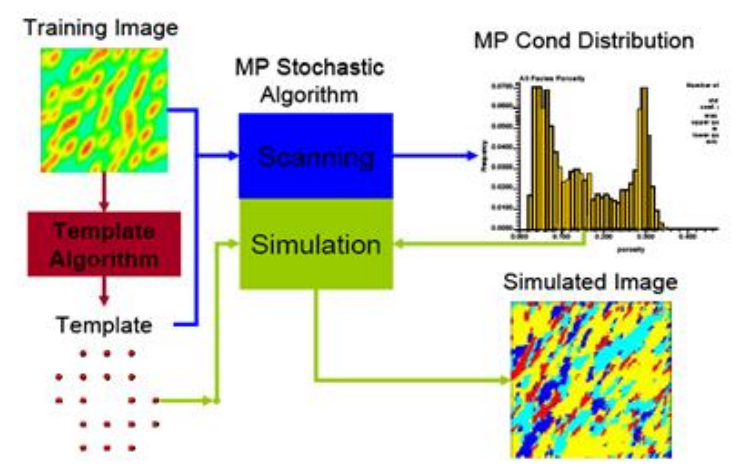

Gambar 1. Skematik dari Multiple Point Statistic (Barrera,2006)

\section{METODOLOGI PENELITIAN}

Pada penelitian ini dilakukan pemodelan sebaran sand dengan menggunakan tiga pendekatan stokastik berbasis grid yaitu Sequential Indicator Simulation (SIS), Truncated Gaussian Simulation (TGS) dan Multipoint Geostatistics (MPG) dengan menggunakan training image yang didasarkan pada data singkapan pada formasi Missisauga, lapangan Penobscot, Kanada. Melalui pemodelan ini diharapkan diperoleh peta distribusi sand untuk formasi ini.

Data

Data yang digunakan adalah data seismik 2D dan dua data sumur Penobscot L-30 dan Penobscot B-40 yang diperoleh dari lapangan Penobscot berlokasi di basin Scotian lepas pantai Nova Scotia Kanada dengan koordinat $44^{\circ} 10^{\prime}$ Lat., and 60 $04^{\prime}$ ' W Long sekitar $280 \mathrm{~km} E S E$ dari Hallifax dan $25 \mathrm{~km} N N W$ dari Sable Island. Spesifikasi data seismik dapat dilihat pada Tabel 1

Tabel 1. Spesifikasi data seismik

\begin{tabular}{|c|c|c|c|c|}
\hline \multicolumn{5}{|c|}{ Geometry 2D Seismic Penobscot } \\
\hline Line & $\mathrm{X}$ & $\mathrm{Y}$ & Trace from & Trace to \\
\hline $02 \mathrm{C}$ & 751172 & 4896654 & 1 & 2304 \\
\hline $03 \mathrm{C}$ & 750927 & 4897681 & 1 & 2326 \\
\hline $04 \mathrm{C}$ & 750051 & 4898445 & 1 & 2346 \\
\hline $05 \mathrm{C}$ & 749808 & 4899446 & 1 & 2366 \\
\hline $06 \mathrm{C}$ & 749880 & 4900557 & 1 & 2369 \\
\hline $07 \mathrm{C}$ & 749832 & 4901476 & 1 & 2406 \\
\hline $08 \mathrm{C}$ & 748711 & 4903263 & 1 & 2444 \\
\hline 44 & 729319 & 4901566 & 1 & 967 \\
\hline 45 & 732131 & 4902493 & 1 & 1015 \\
\hline 46 & 735922 & 4902807 & 1 & 966 \\
\hline 47 & 739266 & 4904545 & 1 & 1075 \\
\hline \multicolumn{2}{|c|}{ Time / Depth Top } & $-20 \mathrm{~ms}$ & & \\
\hline \multicolumn{2}{|c|}{ Sampling Interval } & $4 \mathrm{~ms}$ & & \\
\hline \multicolumn{2}{|c|}{ Time/Depth Bottom } & $7000 \mathrm{~ms}$ & & \\
\hline \multicolumn{2}{|c|}{ Shift } & 0 & & \\
\hline
\end{tabular}

Sumur Penobscot B-14 berada pada koordinat $x=731133.46$ dan $y=4894307.8$, sumur Penobscot L-30 pada koordinat $x=734338.86$ dan $y=4893837.87$.

Enam marker geologi yang diidentifikasi yaitu Banquerau, Wyndot, Logan Canyon, Missisauga dan Abenaki (Clack, W.J.F, \& Crane, J.D.T, 1992). Formasi Missisauga merupakan target dari penelitian ini. Pada formasi tersebut teridentifikasi tujuh lapisan 
sand yang akan diprediksi distribusinya (Tabel 2). Pemodelan distribusi fasies akan dilakukan pada sand\#4, sand\#5, sand\#6 dan sand\#7.

Tabel 2. Tujuh lapisan sand yang teridentifikasi pada formasi Missisauga

\begin{tabular}{|c|l|c|c|}
\hline \multirow{4}{*}{ FORMASI } & \multicolumn{1}{|c|}{$\begin{array}{c}\text { Sumur 1 } \\
\text { (L-30) }\end{array}$} & $\begin{array}{c}\text { Sumur 2 } \\
\text { (B-41) }\end{array}$ \\
\cline { 2 - 4 } & WD (m) & 137.5 & 118 \\
\cline { 2 - 4 } & RT (m) & 29.9 & 29.9 \\
\cline { 2 - 4 } & $\begin{array}{l}\text { Lapisan } \\
\text { Sand }\end{array}$ & $\begin{array}{l}\text { Kedalaman } \\
\text { Bor dari RT } \\
\text { Missisauga }\end{array}$ & $\begin{array}{l}\text { Kedalaman } \\
\text { Bor dari RT } \\
\text { (m) }\end{array}$ \\
\hline \multirow{7}{*}{ (m) } & Sand\#1 & 2478.1 & 2486.7 \\
\cline { 2 - 4 } & Sand\#2 & 2499.7 & 2520.1 \\
\cline { 2 - 4 } & Sand\#3 & 2543.4 & 2543.1 \\
\cline { 2 - 4 } & Sand\#4 & 2637.6 & 2630.5 \\
\cline { 2 - 4 } & Sand\#5 & 2699.1 & 2697.6 \\
\cline { 2 - 4 } & Sand\#6 & 2795.3 & 2788.2 \\
\cline { 2 - 4 } & Sand\#7 & 2835.3 & 2841.8 \\
\hline
\end{tabular}

\section{Pengolahan data}

Proses yang dilakukan pada data dapat dilihat pada skema yang ada di Gambar 2.

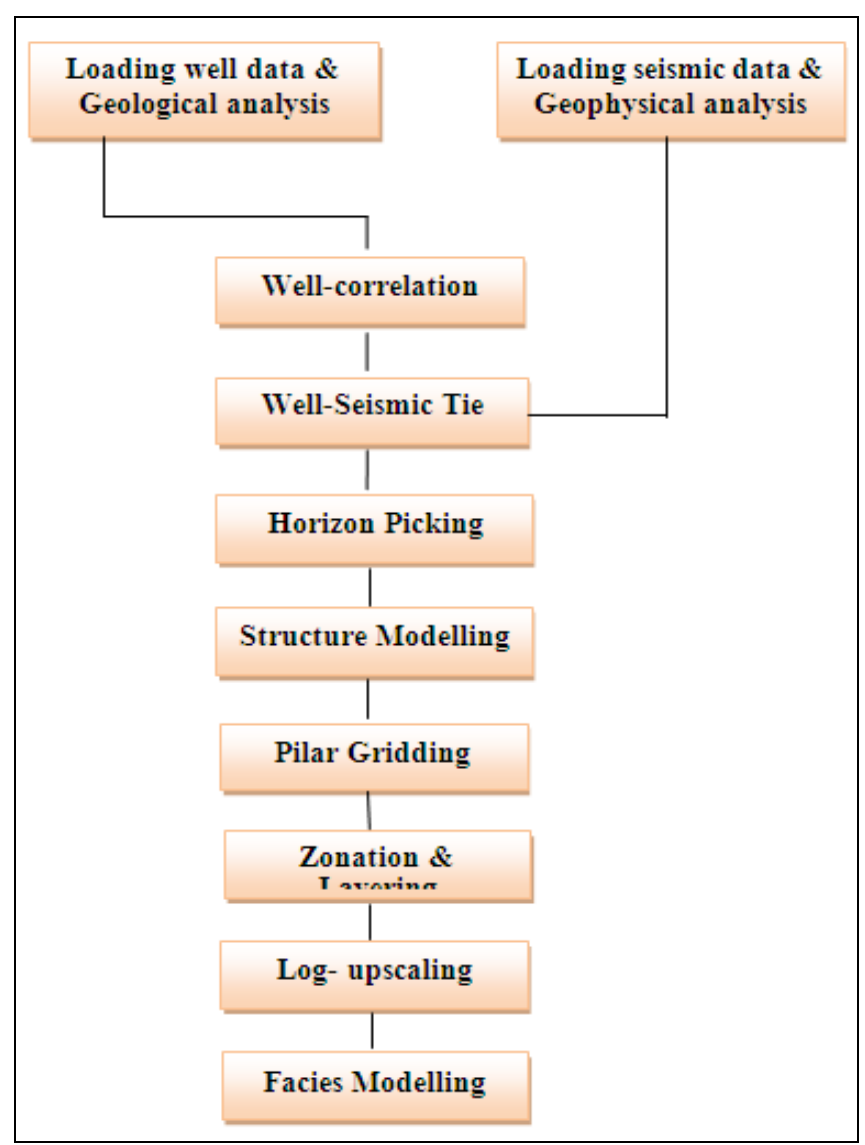

Gambar 2. Flowchart pemodelan fasies 


\section{HASIL DAN PEMBAHASAN}

Proses korelasi antara kedua sumur (well-correlation), pengikatan antara data sumur dan data seismik (well-seismic tie), horizon-picking, pemodelan struktur (structuremodelling), pillar gridding, zonation dan layering dan logs-upscaling dilakukan sehingga diperoleh proporsi facies yang telah di upscaled (upscaled facies proportions) seperti pada Tabel 3

Tabel 3. Proporsi fasies upscaled dari lapisan-lapisan sand

\begin{tabular}{|c|c|c|}
\hline Lapisan sand & $\begin{array}{c}\text { Well-logs } \\
(\%)\end{array}$ & $\begin{array}{l}\text { Upscaled } \\
\text { cells }(\%)\end{array}$ \\
\hline \multicolumn{3}{|l|}{ Sand\#4 } \\
\hline Sand & 20.8 & 19.3 \\
\hline Shaly-sand & 54.2 & 50.2 \\
\hline Shale & 25.0 & 30.6 \\
\hline \multicolumn{3}{|l|}{ Sand\#5 } \\
\hline Sand & 52.4 & 49.9 \\
\hline Shaly-sand & 38.1 & 40.0 \\
\hline Shale & 9.5 & 10.1 \\
\hline \multicolumn{3}{|l|}{ Sand\#6 } \\
\hline Sand & 50.0 & 48.0 \\
\hline Shaly-sand & 36.4 & 39.7 \\
\hline Shale & 12.3 & 13.6 \\
\hline \multicolumn{3}{|l|}{ Sand\#7 } \\
\hline Sand & 77.3 & 62.4 \\
\hline Shaly-sand & 13.6 & 19.0 \\
\hline Shale & 13.7 & 9.1 \\
\hline
\end{tabular}

Nilai proporsi fasies upscaled pada Tabel 2 merupakan input dalam realisasi pemodelan distribusi sand. Realisasi model fasies dengan metode SIS dapat dilihat pada Gambar 3. Dari Gambar 3 objek geologi yang diiinginkan berupa sand channel (berwarna kuning) terlihat namun fasies tidak berurutan sand-shalysand-shale (non-ordered). Realisasi model fasies dengan metode TGS dapat dilihat pada Gambar 6. Dari Gambar 4 dapat dilihat bahwa sand channel (kuning) terlihat lebih defenitif dibandingkan SIS dan sudah terlihat keter-urutan fasies. Realisasi model fasies dengan metode MPG dapat dilihat pada Gambar 5. Training image yang dipakai adalah fluvial sand geometries karena formasi Missisauga merupakan lingkungan pengendapan dominasi sungai. Objek untuk pemodelan sungai (fluvial) adalah sebuah channel, levee dan crevasse sand seperti terlihat pada Gambar 5. Dengan menggunakan training image ini beserta input pola fasies masing-masing lapisan pada MPG diperoleh realisasi seperti pada Gambar 5 (model ini merupakan hasil slice dari model 3D yang dibuat untuk volumetrik formasi Missisauga) 


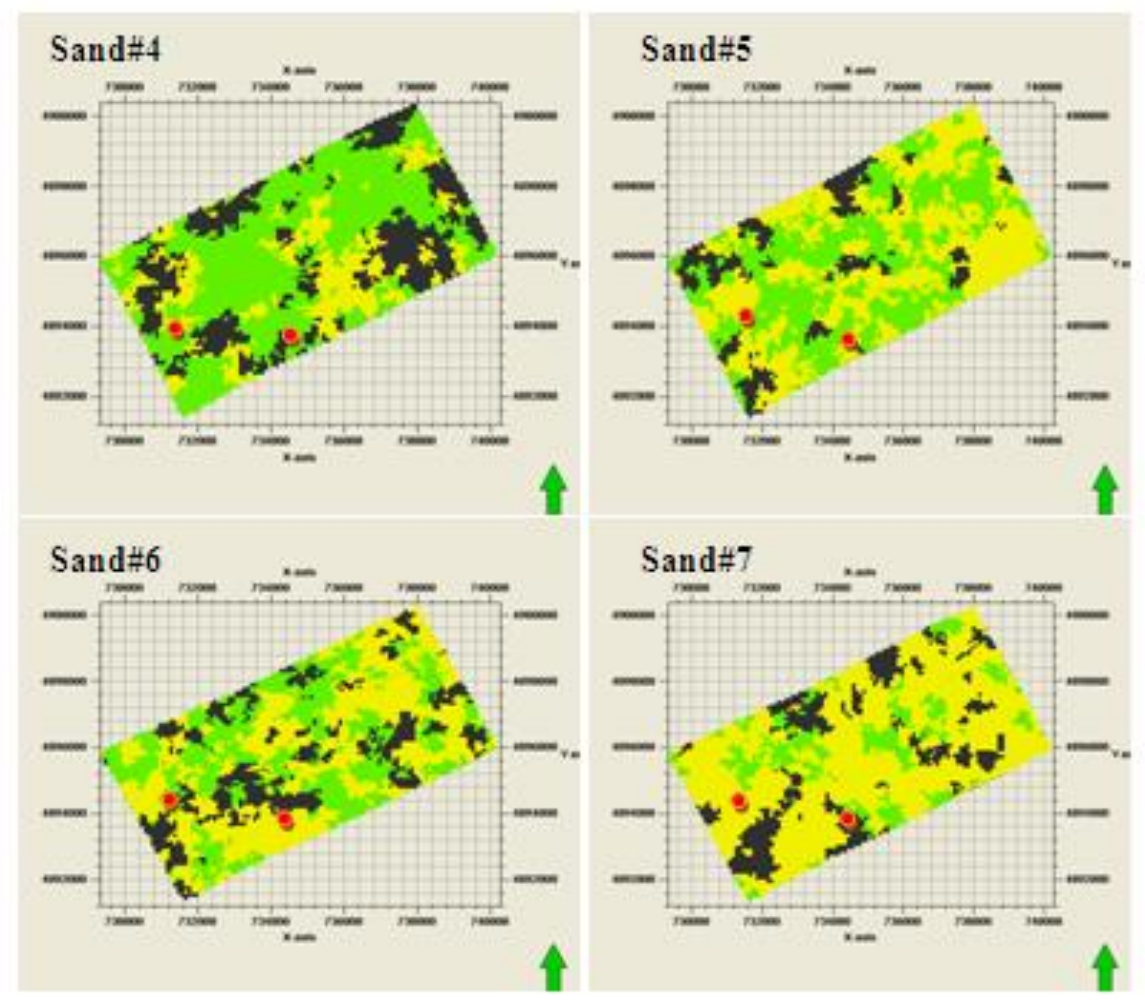

Gambar 3. SIS model untuk Sand\#4, Sand\#5, Sand\#6 dan Sand\#7 (kuning : sand, hijau : shaly sand, hitam : shale, dua titik merah:sumur)
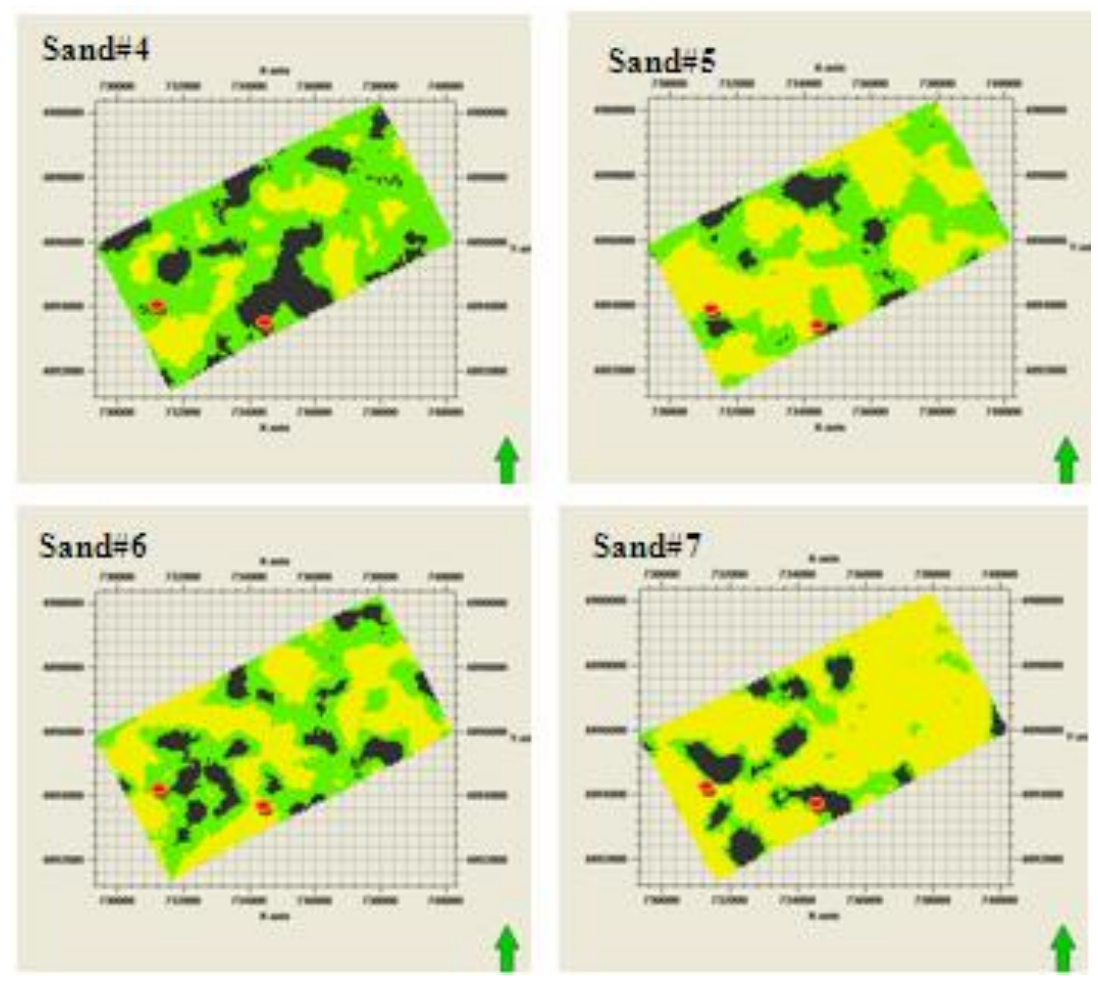

Gambar 4. TGS model untuk Sand\#4, Sand\#5, Sand\#6 dan Sand\#7 (kuning : sand, hijau : shaly sand, hitam : shale, dua titik merah: sumur) 


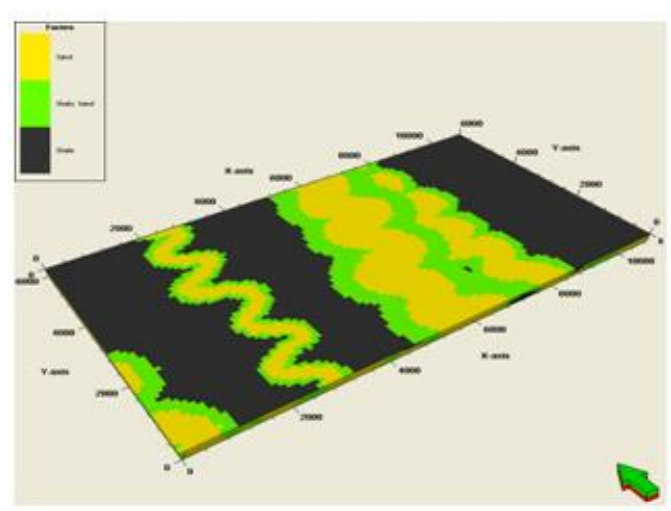

Gambar 5 Training image untuk MPS

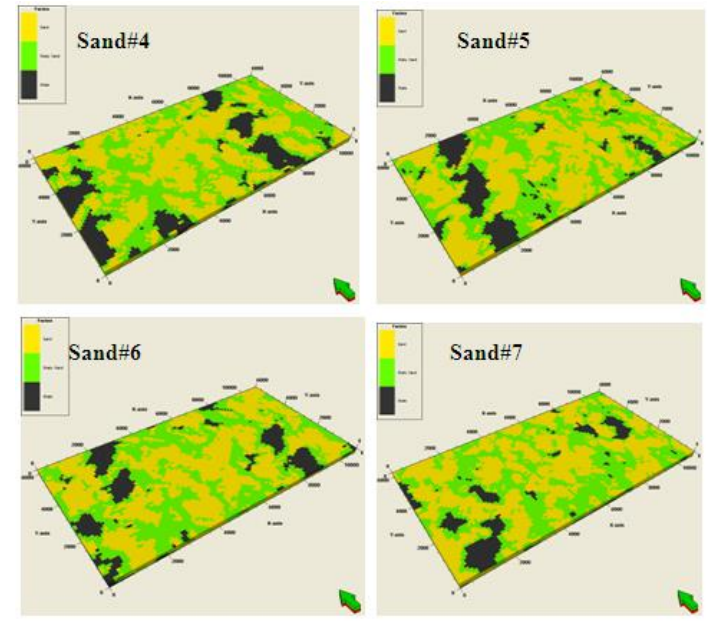

Gambar 6. MPG model untuk Sand\#4, Sand\#5, Sand\#6 dan Sand\#7 (kuning : sand, hijau:shaly sand, hitam:shale, dua titik merah : sumur)

Dari model yang dihasilkan terlihat sand channel defenitif dan kemenerusan terlihat lebih baik namun fasies terlihat non-ordered. Hal ini kemungkinan disebabkan oleh belum optimalnya parameter training image yang digunakan dalam pemodelan seperti skala, arah anisotropi dan trend fasies akibat kurang lengkapnya informasi geologi yang tersedia. Terlepas dari itu MPG menawarkan representasi kemenerusan lateral dan vertikal dari lapisan sand karena menggunakan pemodelan geologi volumetric.

\section{KESIMPULAN}

Berdasarkan hasil yang diperoleh dapat disimpulkan bahwa untuk kasus ini pemodelan MPG merupakan metode yang cukup baik digunakan untuk menampilkan fitur geologi berupa sand channels dengan kemenerusan lateral namun untuk keterurutan distribusi fasies, metode TGS lebih unggul.

\section{DAFTAR KEPUSTAKAAN}

1. Cáceres et al. (2010). Truncated gaussian kriging as an alternative to indicator kriging. February 12, 2012. http://geoinnova.cl/pdf/truncated gaussian kriging.pdf 
2. Caers, J., \& Zhang, T. (2002). Multiple-point geostatistics: a quantitative vehicle for integrating geologic analogs into multiple reservoir models In: Integration of outcrop and modern analog data in reservoir models. AAPG Mem, 80,383-394.

3. Clack, W.J.F, \& Crane, J.D.T, (1992). Penobscot Prospect: geological evaluation and oil reserve estimates. Report for Nova Scotia Resources (Ventures) Ltd.

4. Deutsch, C.S. (2002). Geostatistical reservoir modelling. USA: Oxford University Press.

5. Falivene et al. (2007). Statistical grid-based facies reconstruction and modeling for sedimentary bodies: Aluvial-palustrine and turbiditic examples. Geologica Acta, Vol.6, No.8, 199-230.

6. Strebelle, S. (2005) Multiple point statistics. Proceedings of IAMG '05, The Annual Conference of The International Association for Mathematical Geology, Toronto

7. Strebelle, S. (2002). Conditional simulation of complex geological structures using multiple-point statistics. Mathematical Geology. 34, No. 1, 1. 